\title{
HOW MINERALOGY AND GEOCHEMISTRY CAN IMPROVE THE SIGNIFICANCE OF Pb ISOTOPES IN METAL PROVENANCE STUDIES*
}

\author{
S. BARON $\dagger$ \\ Laboratoire des Travaux et Recherches Archéologiques sur les Cultures, les Espaces et les Sociétés (TRACES), \\ CNRS UMR 5608, Université de Toulouse 2 Le Mirail, Maison de la Recherche, 5 allées Antonio-Machado, \\ 31058 Toulouse Cedex 09, France \\ C. G. TĂMAŞ \\ Department of Geosciences, University of Fribourg, 6, chemin du Musée, 1700 Fribourg, Switzerland, and \\ Faculty of Biology and Geology, University Babeş-Bolyai, 1, M. Kogălniceanu str., 400084, Cluj-Napoca, Romania \\ and C. LE CARLIER \\ Centre de Recherches en Archéologie, Archéosciences, Histoire, CNRS UMR 6566, Université Rennes 1, Bat. 24-25, \\ Campus de Beaulieu Rennes, Cedex, France
}

\begin{abstract}
Lead isotopes combined with trace element data represent a powerful tool for non-ferrous metal provenance studies. Nevertheless, unconsidered geological factors and archaeological data, as well as ignored analytical procedures, may substantially modify the interpretation of the isotopic and trace element signature obtained as a potential ore candidate. Three archaeological examples, accompanied by high-resolution lead isotopic measurements (MC-ICP$M S)$, are presented here to discuss the above-mentioned criticisms and to propose some solutions. The first example deals with prehistoric/historical gold/silver-mining activity from Romania (the Baia Borşa and Roşia Montană ore deposits). The second one regards the lead/silver metallurgical activity from the Mont-Lozère massif (France) during medieval times. The third example focuses on the comparison between two batches of lead isotope data gathered on Roman lead ingots from Saintes-Maries-de-la-Mer, using different SRM $981 \mathrm{~Pb}$ values.
\end{abstract}

\begin{abstract}
KEYWORDS: MINERALOGY, MINING ARCHAEOLOGY, GEOCHEMISTRY, ARCHAEOLOGICAL ORES, Pb ISOTOPES, NIST SRM 981 Pb VALUES,
\end{abstract} METAL PROVENANCE

\section{INTRODUCTION}

Since the beginning of the 1980s, numerous non-ferrous metal provenance studies based on chemical elemental signature and lead isotopic compositions have been carried out successfully and they highlight various archaeological and historical challenges. These metal provenance studies contribute to the reconstruction of the trade routes in ancient metals, and help us to better understand the economic, political and social aspects of ancient civilizations (e.g., Stos-Gale et al. 1997; Gale 1999; Sayre et al. 2001; Niederschlag et al. 2003; Baron et al. 2011). It is beyond the scope of this paper to present the theory behind the use of lead isotopes in 
geochronology: more details are reported elsewhere (Marcoux 1986; Faure and Mensing 2005; Allègre 2008). We only recall that three stable $\mathrm{Pb}$ isotopes out of four, ${ }^{206} \mathrm{~Pb},{ }^{207} \mathrm{~Pb}$ and ${ }^{208} \mathrm{~Pb}$, are radiogenic (time dependent) and that they are produced by the radioactive decay of ${ }^{238} \mathrm{U}$, ${ }^{235} \mathrm{U}$ and ${ }^{232} \mathrm{Th}$, respectively. The ${ }^{204} \mathrm{~Pb}$ isotope is stable (time independent) and its abundance has been constant since the Earth's formation. The abundances of the four lead isotopes are approximately $52.4 \%, 22.1 \%, 24.1 \%$ and $1.4 \%$ for ${ }^{208} \mathrm{~Pb},{ }^{207} \mathrm{~Pb},{ }^{206} \mathrm{~Pb}$ and ${ }^{204} \mathrm{~Pb}$ respectively. Since the introduction of multicollector-inductively coupled plasma-mass spectrometry (MCICP-MS) in the mid-1990s, it has been possible to measure several isotopes simultaneously, with a high mass resolution (Rehkämper and Halliday 1998). These new spectrometers permit notable advances in geochemistry, and more recently in archaeology too. The presentday precise and accurate measurements improve the tracing by increasing the analytical precision by a factor of 10 over that obtainable with routine thermal ionization mass spectrometry (TIMS), and comparable to the precision of TIMS with double or triple spiking. MC-ICP-MS also allows the measurements of new isotopic tracers such as $\mathrm{Cu}, \mathrm{Fe}, \mathrm{Sn}$ and so on (called 'non-traditional isotopes') (Yi et al. 1999; Poitrasson et al. 2004; Mason et al. 2005). The isotopic data measured nowadays by MC-ICP-MS are more significant and relevant, and they can be more accurately interpreted.

This paper discusses several points which, together, significantly improve metal provenance studies undertaken using high-resolution measurements: (i) to study and understand the geological context of the ores from a given ore body/ore deposit/mining district that is supposed to represent an ancient ore source; (ii) to provide representative ore samples from a geological perspective; (iii) to establish the relevance of the ore samples from the archaeological viewpoint (i.e., whether or not they might be related to proven ancient mining activity); (iv) to adapt the scale of the study - that is, to focus on district/regional isotopic ores data instead of referring broadly to the European/Mediterranean scale; (v) to report the NIST SRM $981 \mathrm{~Pb}$ and NIST SRM $997 \mathrm{Tl}$ standard reference values used for normalization; and (vi) to have systematic recourse to ${ }^{204} \mathrm{~Pb}$ for optimizing isotopic tracing by using diagrams in which all three radiogenic isotopes are ratioed to ${ }^{204} \mathrm{~Pb}$. Furthermore, the benefits of using the above-mentioned methods are highlighted through several archaeological examples (with original and published results). Other recent reviews on metal provenance studies have been carried out by Pollard (2008) and Stos-Gale and Gale (2009), as well as a lead isotope inventory by Cattin et al. (2009).

\section{THE ORE GEOLOGY-THE MOST IMPORTANT FACTOR TO IMPROVE THE SIGNIFICANCE OF $\mathrm{Pb}$ ISOTOPES IN METAL PROVENANCE STUDIES}

A sensitive part of any metal provenance study based on lead isotopes is the evaluation of the lead isotopic compositions of the available or presumed ore bodies in comparison with those of a given metallic artefact.

\section{The 'ore databases': use and relevance}

Over recent decades, many metal provenance studies have used several 'ore databases' established during the 1990s by various laboratories (e.g., Pernicka et al. 1990; Yener et al. 1991; Sayre et al. 1992; Rohl 1996; Stos-Gale et al. 1998; Gale 1999). These databases are valuable and they allow us to reject some geographical regions as potential sources within a given metal provenance study. Previous criticisms regarding these ore databases (Budd et al. 1993, 1996; Scaife et al. 1994; Ixer 1999) focused on their mineralogical and geochemical complexities and 
their isotopic treatments, but not at all on their choices of mining district or their isotope data acquisition. Nevertheless, up to now these ore databases have been used and reused intensively, neglecting their possible limitations. Nowadays, different and unequal databases exist and are used across Europe: thus far, metal provenance studies are often based on them without the necessary adjustments.

Indeed, the classical Mediterranean and European ore databases are imperfect due to: (i) the scarce mineralogical studies of ancient ores on the ore deposit scale; (ii) the lack of archaeological evidence of ancient mining works in a given ore district; (iii) the small number of analysed samples for a given ore body/deposit/district ( $n$ is often $<10$ ), which impedes an accurate mineralogical, trace element and $\mathrm{Pb}$ isotope characterization of the mining site (Ixer 1999); (iv) the very few archaeologically oriented geological studies of ore bodies from a given mining district (Ixer 1999); and (v) the systematic consideration of several very well-known 'star' deposits as metal sources, ignoring other possible sources.

\section{The ore deposits: similarities and heterogeneities}

The lead isotopic compositions of a given ore district/deposit are controlled by four main geological factors: (i) the origin(s) of the metal(s) (primary, inherited, mixing); (ii) the origin(s) of the mineralized fluids (crust or mantle) and the fluid/wall-rock interaction; (iii) the age of the deposits; and (iv) the time span of ore deposition from the given mining district. Moreover, each mineralization sequence/event of an ore body/ore deposit may have its distinct isotopic composition due to the variation of the above-mentioned control factors.

Heterogeneous isotopic compositions are known for different ore sequences within a single ore body (e.g., Marcoux and Bril 1986). A long period of ore deposition can also generate a significant isotopic variation related to radioactive decay of ${ }^{238} \mathrm{U},{ }^{235} \mathrm{U}$ and ${ }^{232} \mathrm{Th}$, the fathers of ${ }^{206} \mathrm{~Pb},{ }^{207} \mathrm{~Pb}$ and ${ }^{208} \mathrm{~Pb}$, respectively (Deloule and Allègre 1986; Faure and Mensing 2005). On the other hand, a superposed later geological event-such as, for example, the Variscan orogeny in France-could remobilize some pre-existing (pre-Variscan) ore deposits and produce new deposits with narrower isotopic composition fields (Brévart et al. 1982). Another example producing a narrower isotopic composition field is the remobilization of Triassic ore deposits from southern Cevennes during the late Bathonian emergence (Le Guen and Lancelot 1989).

On the scale of a given ore deposit/ore body, significant lead isotope variations have been already noted. For example, the small-sized Baia Borşa ore field (NW Romania) fits to two lead isotope fields (Baia Borsa lead isotopic data; Fig. 1) corresponding to two mineralization events that overlap on the same area (Cook and Chiaradia 1997). Consequently, Baia Borsa has two different lead isotope signatures corresponding to these different metallogenetic phases; the first one represented by Caledonian metamorphosed volcanic hosted massive sulphides (VHMS) ores, and the second consisting of Neogene epithermal ores. Contrasting with the above-mentioned mining districts, the lead isotopic compositions of Mont-Lozère massif (SE of the Central Massif, France) plot only in one field, which corresponds to one ore deposition event (Fig. 1) (Baron et al. 2006). In spite of its small size, the Montmirat ore occurrence within Mont-Lozère shows isotopic compositions that overlap an important part of the Mont-Lozère mining district (Fig. 1).

On the other hand, ore bodies situated in different geographical locations may have similar lead isotopic signatures, due to similar ore sources and, thus, the $\mathrm{Pb}$ isotope data of several ore deposits/ore districts frequently overlap. For example, the lead isotopic fields of ores of the United Kingdom and Ireland (Rohl 1996) overlap partially with that of Sardinia (Stos-Gale et al. 1995). Numerous ore deposits in different geographical locations also overlap. 

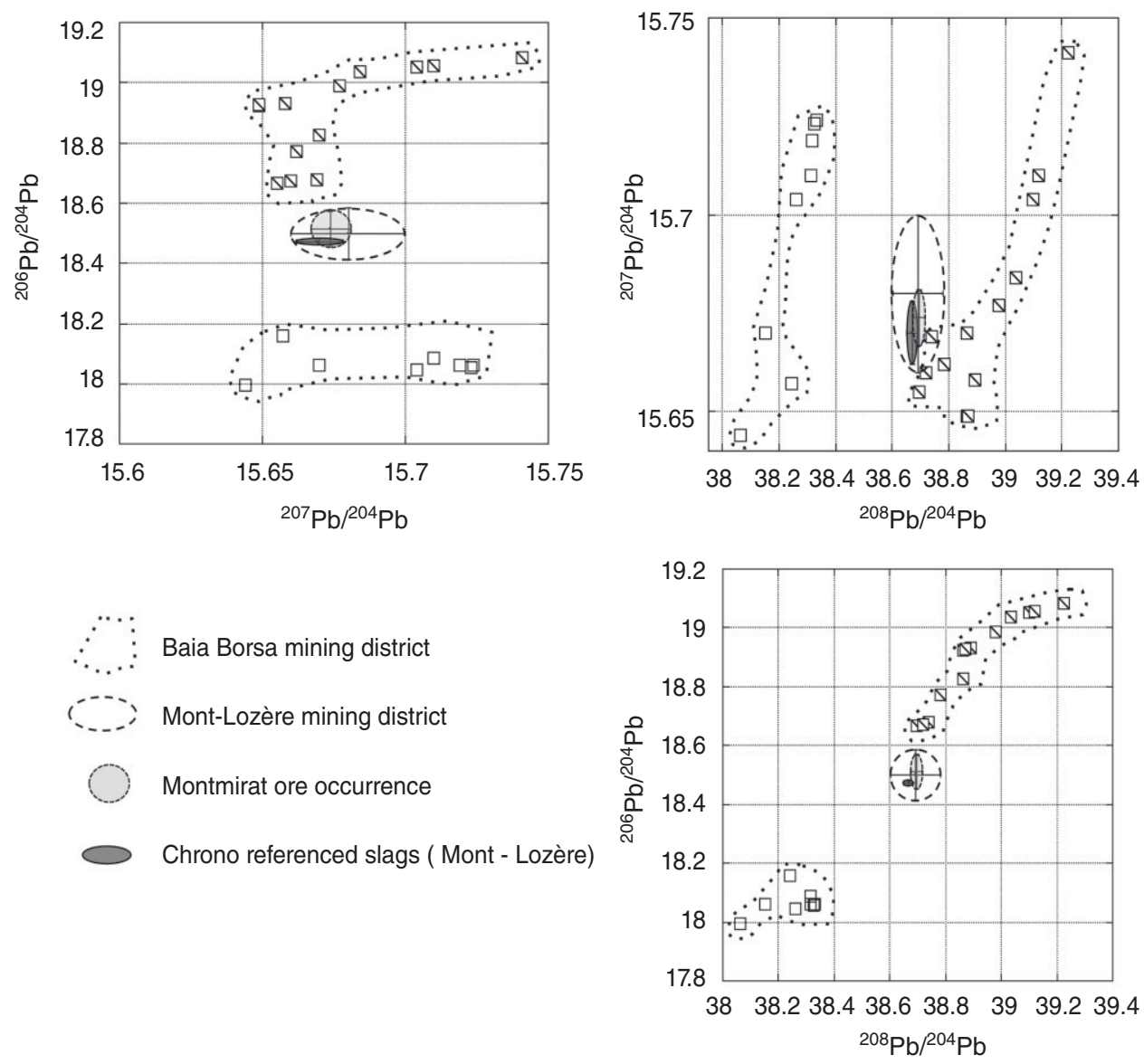

Figure $1 \quad \mathrm{~Pb} / \mathrm{Pb}$ diagrams showing: (i) lead isotopic heterogeneities inside a mining district due to the presence of two superposed mineralization events, illustrated by the Baia Borsa mining district, Romania (Cook and Chiaradia 1997); (ii) several chronologically referenced slags reducing the lead isotopic composition in a given mining period-the medieval slags from Mont-Lozère mining area (Baron et al. 2006); and (iii) lead isotopic heterogeneities inside several ore bodies within an ore district-the Montmirat ore occurrence from the Mont-Lozère mining district (Baron et al. 2006). It should be noted that the error bars are smaller than the dots in Pb/Pb diagrams.

To conclude, the lead isotopic composition of an ore is controlled by multiple geological factors. Each mineral paragenesis (co-genetic mineral assemblage) has its own lead signature, according to its geological control factors. Besides these geological factors, the lead grade and its isotopic composition in the ores are controlled by radioactive decay of the three parent isotopes over geological time and by the initial ${ }^{204} \mathrm{~Pb}$ content of the ores. Two evolutions of the ores and their $\mathrm{Pb}$ isotope composition occur concurrently during the geological history of the Earth: a chronological evolution due to the radioactive decay of the $\mathrm{Pb}$ parent isotopes, and a geological process; that is, geological events involved in the ore genesis and subsequent geological evolution. Taken together, these two evolutionary trends generate the isotopic differentiation of several materials on Earth. Thus, the characterization of the ores and their host rocks by mineralogical studies allows us to understand the genetic conditions within a given mining district, and permits us to identify the mineral deposition events/sequences and their mineral assemblages as well as 
their geological evolution through time (Ixer 1999). The geochemical studies should be carried out on representative/numerous ore samples, according to the field relationships and mineralogical observations carried out on different ore bodies, in order to obtain reliable lead isotopic signatures on the ore deposit scale. This is not really the case in the literature, with very few ore samples being measured and their geological/mineralogical context frequently being ignored. The ores used in metal tracing are often collected from the dump heaps of modern/recent mines or from mineralogical museum collections depleted of significant geological indications about ancient mining.

At present, very small isotopic variations are precisely and accurately measurable according to the high-resolution analyses available today. From this viewpoint, the geological and mineralogical study of the ores and their sampling represent an indispensable step that allows us to obtain relevant isotopic data. It is important to note that even small isotopic variations are particularly useful for solving ancient metal tracing.

The above-mentioned remarks stress the importance of characterizing an ore deposit/district well from the geological/mineralogical point of view, in order: (i) to refine the ore sources isotopic field; (ii) to refine the isotopic tracing of metal provenance studies; and (iii) to point out the specific trace elements signature for a given mining district. We consider that any metal provenance study should start with an ore deposit/mineralogical study of the mining sites, also conducted from a mining archaeological perspective.

\section{THE IMPORTANCE OF KNOWING WHICH ORES WERE ACTUALLY USED BY} ANCIENT METALLURGISTS

\section{The ores exploited by the ancient miners}

The significance of an artefact is emphasized by the archaeological context of its discovery. Similarly, an ore sample has its particular significance within an ore deposit. Frequently, the ore samples used for metal provenance studies are gathered during pedestrian prospection, or they are picked up from recent or abandoned waste dumps, or they come from mineral collections with no geological references except the name, having thus a minor geological and/or archaeological relevance. It is important to stress that the sampling of the ores for archaeological purposes is critical. Often, the ore samples that are supposed to clear up a provenance study are, in fact, depleted of any geological and archaeological significance, this status rendering the conclusions questionable.

Mining archaeologists could provide relevant ore samples - that is, the ores really exploited by the ancient miners-by means of combined archaeological and geological studies of the ancient mines. This approach considerably improves the metal provenance restitution. The discovery of ancient mines is not a chancy hazard, but the product of a real methodological research based on specific knowledge, from geomorphology and archaeology to geology (Domergue 1990, 2008; Goldenberg 1998; Cauuet 2005, 2008). Mining archaeology expertise allows us to identify ancient mines, the exploitation methods, the spatial evolution of the mining and the period of the exploitation (Cauuet 2004, 2008), and also permits us to characterize the archaeological ores exploited by the ancient miners (Tămaş et al. 2009). This is extremely useful when the isotopic signatures of several ore bodies from a deposit are different and only some of them have been exploited in ancient times. Furthermore, mineralogical studies carried out on these archaeological ores facilitate the highlighting of not only the main ore minerals, but also peculiar minerals that can host exotic chemical element(s), which can be used as possible elemental chemical tracer(s) 
for a given deposit or mining district. The use of the elemental tracers together with isotopic data significantly improves the pertinence of provenance studies. For example, in the case of the Roşia Montana site (Apuseni Mountains, Romania), the geological and mineralogical studies have revealed that the precious metal ores (primary ores) exploited during the Roman period (second to third centuries AD) host Te- and Ge-bearing minerals (tellurides, argyrodite and Te-bearing argyrodite). Metallurgical experiments carried out with native gold from Rosia Montana (electrum samples picked up from veins) have demonstrated that tellurium is not removed from the precious metal during smelting, regardless of the redox conditions (Hauptmann et al. 1995), being present in the final product as well. In this case, the use of trace elements, coupled with the isotopic signatures of the geological and chronological referenced ores and this experimental approach, is valuable in improving future metal provenance studies (Tămaş et al. 2009). Generally, if a mining district hosts specific trace(s) element(s), such as Te and Ge in the abovementioned example, it would be useful to take the trace elements into consideration for future metal tracing (Hauptmann et al. 1995; Ixer 1999).

Geological and ore deposit research coupled with mining archaeology studies in a given mining district allow us to obtain ore samples with archaeological significance. The highresolution isotopic measurements applied on these referenced materials increase the archaeological significance of the isotopic data of the ore sources and improve the tracing for future metal provenance studies (Baron et al. 2011).

The combined geological and archaeological research within a mining site allows us: (i) to identify the ores really exploited by the ancient miners; (ii) to point out the metal(s) exploited in a mine/mining district during a given time; (iii) to gather the lead isotope signatures of the ores mined by the ancient miners in a given period of exploitation; and (iv) to focus studies on the regional scale, on the basis of accurate archaeological data. These different points are crucial to resolve provenance studies with regard to the improvement of the isotope discrimination available today, where the developments are continuously pushed forwards. Additionally, according to the above discussions, the ore sampling and the significance of the ores has become a crucial step.

\section{The ancient slags: waste materials reflecting metallurgical activities at the local/regional scale}

When no archaeological ores are available, the metallurgical wastes could be also good candidates for metal provenance studies, if their age is also known (Ploquin et al. 2003; Baron et al. 2006). The slags, their associated charcoals and other artefacts discovered during archaeological excavations represent evidence of ancient metallurgical activities in a given space and time. Not only do mineralogical and chemical analyses of the slags allow us to understand some metallurgical processes, but they also allow us (i) to identify an elemental tracer linked to the geological context in a given space/time, and (ii) to attribute an elementary and isotopic mean composition to an ancient metallurgical activity. For example, the metal prills from the slags formed during the processing of Ag-bearing galena ores from the Mont-Lozère Massif (France) reflect both the chemical (major and trace elements) and lead isotopic compositions of the metal produced in this mining district at a given time (Baron et al. 2006, 2009) (Fig. 1).

Moreover, the use of the metal prills hosted within slags is more appropriate than the silicate matrix of the slags, because the metal prills also reflect the possible ore mixing and/or additions needed for metal(s) production in a given area (Baron et al. 2009). New $\mathrm{Pb}$ isotopic data were acquired on the slags' silicated matrix, using the same slags from which the metal prills had been previously analysed by Baron et al. (2006) (Table 1). $\mathrm{Pb} / \mathrm{Pb}$ diagrams (Fig. 2) show the 
Table 1 Lead isotope data from silicated matrix and metal prills of slags from Mont-Lozère massif, France

\begin{tabular}{|c|c|c|c|c|c|}
\hline Slags ID & ${ }^{208} \mathrm{~Pb}{ }^{206} \mathrm{~Pb}$ & ${ }^{207} \mathrm{~Pb} /{ }^{206} \mathrm{~Pb}$ & ${ }^{208} \mathrm{~Pb}{ }^{204} \mathrm{~Pb}$ & ${ }^{207} \mathrm{~Pb} /{ }^{204} \mathrm{~Pb}$ & ${ }^{206} \mathrm{~Pb}{ }^{204} \mathrm{~Pb}$ \\
\hline \multicolumn{6}{|l|}{$\mathrm{Pb}$ in metal prills } \\
\hline Site 18 & 2.09075 & 0.84715 & 38.663 & 15.666 & 18.492 \\
\hline Site 60 & 2.09383 & 0.84822 & 38.673 & 15.666 & 18.470 \\
\hline Site 45 & 2.09578 & 0.84905 & 38.672 & 15.667 & 18.453 \\
\hline Site 3 & 2.09218 & 0.84716 & 38.776 & 15.701 & 18.534 \\
\hline Site $5^{\prime \prime}$ & 2.09372 & 0.84816 & 38.681 & 15.669 & 18.475 \\
\hline Site 7 & 2.09453 & 0.84870 & 38.660 & 15.665 & 18.458 \\
\hline Site 22 & 2.09382 & 0.84822 & 38.680 & 15.669 & 18.473 \\
\hline Site 8 & 2.09385 & 0.84822 & 38.682 & 15.670 & 18.474 \\
\hline Total external uncertainties ( $2 \sigma)$ & 0.00005 & 0.00005 & 0.002 & 0.001 & 0.002 \\
\hline \multicolumn{6}{|l|}{$P b$ in silicated matrix } \\
\hline Site18 & 2.09210 & 0.84763 & 38.681 & 15.672 & 18.489 \\
\hline Site 3 & 2.09005 & 0.84644 & 38.703 & 15.674 & 18.518 \\
\hline Site $5^{\prime \prime}$ & 2.09407 & 0.84800 & 38.701 & 15.672 & 18.481 \\
\hline Site 60 & 2.09511 & 0.84836 & 38.700 & 15.671 & 18.472 \\
\hline Site 45 & 2.09661 & 0.84906 & 38.693 & 15.669 & 18.455 \\
\hline Site 3 & 2.09111 & 0.84677 & 38.713 & 15.677 & 18.513 \\
\hline Site 7 & 2.09567 & 0.84872 & 38.695 & 15.671 & 18.464 \\
\hline Site 22 & 2.09659 & 0.84910 & 38.682 & 15.666 & 18.450 \\
\hline Site 8 & 2.09406 & 0.84787 & 38.704 & 15.671 & 18.483 \\
\hline Total external uncertainties $(2 \sigma)$ & 0.00051 & 0.00017 & 0.012 & 0.004 & 0.003 \\
\hline
\end{tabular}

Reference values for SRM $981 \mathrm{~Pb}$ and SRM 997 TI were taken from Thirlwall (2002).

lead isotopic data shift between the silicated matrix and the metal prills in the case of several slags from Mont-Lozère Massif (France). These lead isotopic differences, measured between the metal and the silicated matrix of the same slags, are greater than the total external uncertainties of samples (triplicates), and consequently they are relevant and interpretable (Table 1). Some archaeological experiments, coupled with lead isotopic measurements by MC-ICP-MS for the medieval period, conducted on the smelting of high-grade $\mathrm{Pb}$ ores (silver-rich galena), show the same trend; that is, isotopic differences that might be due to lead additions at the beginning of the reduction of ores, in order to facilitate the recovery of the silver directly from the galena (Baron et al. 2009). During the chaîne opératoire for argentiferous lead in the medieval period, an isotopic bias might be possible (Baron et al. 2009). In the case study of the Mont-Lozère massif, the measured isotopic bias reinforces the determination of the origin of the ores through the overlapping of the lead isotopic values for the silicated slags on to the ores of Montmirat and les Bondons, as has been previously defined on metal prills of these same slags (Baron et al. 2006) (Fig. 2). In this case study, the isotopic bias for future metal provenance studies on the Mont-Lozère massif is negligible. Nevertheless, the isotopic bias could be important in the case of ores containing a low $\mathrm{Pb}$ content. For example, for the smelting of copper and tin ores, the lead contribution from the tuyères and the lining could produce an important isotopic bias.

The $\mathrm{Pb}$ signature of metal prills included in the silicate matrix of the slags is more reliable than those of heterogeneous ores, and it corresponds to the signature of the metal produced in a given region at a given time. Furthermore, metal prills also reflect the possible additions made during 

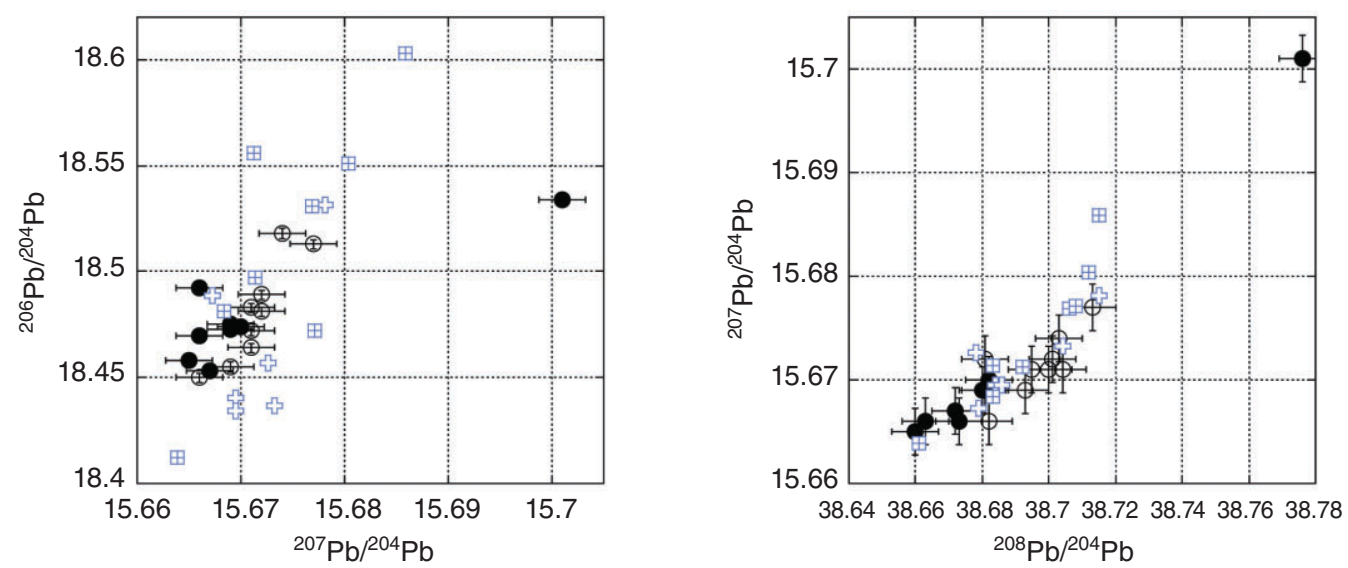

- $\mathrm{Pb}$ in metal prill (This study)

O $\mathrm{Pb}$ in silicated matrix (This study)

- Les Bondons Ore Occurrence (Baron et al., 2006)

田 Montmirat Ore Occurrence (Baron et al., 2006)

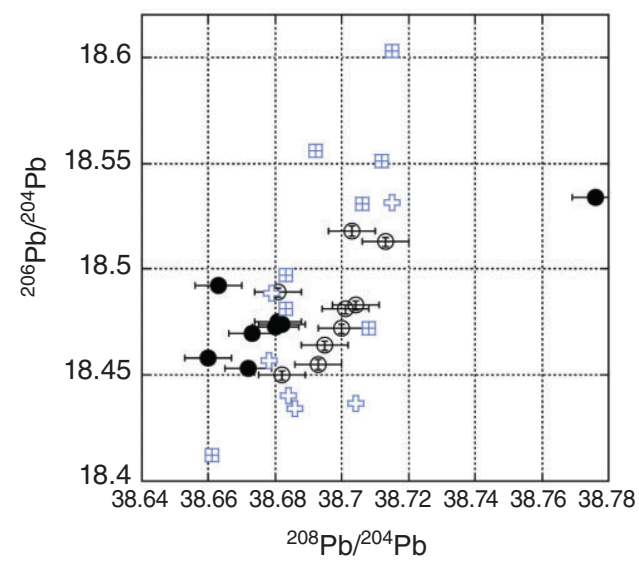

Figure $2 \mathrm{~Pb} / \mathrm{Pb}$ diagrams showing the isotopic bias between the metal prills and the silicated matrix of the same slag. The diagram is based on eight different slags, which have been measured, and all show the same trend. The existing bias is apparently due to $\mathrm{Pb}$ additions during metallurgical processes or ore mixing, at least in the case of the Mont-Lozère study (Baron et al. 2006, 2009).

the chaîne opératoire. To conclude, the comparison between the metal prills and the silicate matrix of a slag becomes crucial in understanding the chaîne opératoire in a given local metal production.

\section{THE REPORTING AND INTERPRETATION OF LEAD ISOTOPIC RATIOS}

The Standard Reference Material (SRM) $981 \mathrm{~Pb}$ is the common lead isotopic standard used by laboratories around the world to measure isotopic compositions. In a given analytical session, the repeated measurement of NIST SRM $981 \mathrm{~Pb}$ permits the validation of the lead isotopic data during a given analytical session; that is, their accuracy. If the isotopic data are accurate, it is possible to compare the lead isotopic data of samples between several laboratories.

In the geochemical literature, the isotopic data obtained after the introduction of MC-ICP-MS facilitated isotopic comparisons between high-resolution measurements (using 
mainly $\mathrm{Tl}$ doping to improve the ${ }^{204} \mathrm{~Pb}$ measurement and also allowing a strong correction for interference for the ${ }^{204} \mathrm{Hg}$ isotope) and isotopic data acquired by TIMS $\left({ }^{204} \mathrm{~Pb}\right.$ occasionally being measured using double or triple spiking). Consequently, it was necessary to re-evaluate the SRM $981 \mathrm{~Pb}$ ratios in order to fit with the SRM $981 \mathrm{~Pb}$ values gathered by TIMS using double or triple spiking. As a result, several authors proposed new values of SRM $981 \mathrm{~Pb}$ (Table 2), and several values of SRM $981 \mathrm{~Pb}$ and SRM $997 \mathrm{Tl}$ are available today (Table 2). So, it is important that, today, each study reports their SRM $981 \mathrm{~Pb}$ values used to correct the mass fractionation during the analysis.

However, in metal provenance studies, high-resolution measurements using TIMS with double or triple spiking were rarely being used 10-15 years ago. At present, the isotopic data obtained by MC-ICP-MS are frequently used in archaeology and are directly compared with old isotopic data acquired by TIMS. The early data are exact, of course, and extremely useful due to several SRM $981 \mathrm{~Pb}$ values being available today (Table 2). So, at present, it is necessary to know, for a given data set using MC-ICP-MS, the SRM $981 \mathrm{~Pb}$ values to be able to correct the data among them. These high-resolution isotopic measurements have been used to propose new interpretation in recent publications. However, for a credible use of isotopic data in metal provenance studies, it is necessary: (i) to indicate the reference material values of the SRM $981 \mathrm{~Pb}$ used for the analytical sessions; (ii) to report the measured reference material values of SRM $981 \mathrm{~Pb}$ and SRM $997 \mathrm{Tl}$ during the analytical sessions; and (iii) to report the three radiogenic isotopes ratioed to

${ }^{204} \mathrm{~Pb}$ in creating the diagrams.

Using an archaeological example (new isotopic data on antique Roman lead ingots), we present below the bias induced by the use of two different SRM $981 \mathrm{~Pb}$ values. Due to the high-precision MC-ICP-MS measurements available today (the $2 \sigma$ error bars are smaller than the symbols in the diagrams), this bias could be important.

\section{The implications of reporting the Standard Reference Material 981 Pb values}

The high-resolution MC-ICP-MS available today is more precise (by a factor of up to 10) than the data produced by TIMS. The MC-ICP-MS isotopic data are as accurate and precise as those of the TIMS double spike (Todt et al. 1996) and/or the TIMS triple spike (Galer and Abouchami 1998). Generally speaking, the vast majority of isotopic data produced by TIMS (thermal ionization mass spectrometry) and used in metal provenance studies were obtained without any spiking technique. Thus, the comparison between two isotopic data sets, one obtained by TIMS without spiking and the other by MC-ICP-MS, could produce an artificial bias if different values of SRM $981 \mathrm{~Pb}$ were used in the two data sets. In order to avoid this bias, the SRM $981 \mathrm{~Pb}$ isotope values of a set of measurements should be given, and the data set adjusted to match those of any comparison database. On the other hand, thallium doping has been developed to optimize the measurement of ${ }^{204} \mathrm{~Pb}$. Indeed, ${ }^{205} \mathrm{Tl}$ and ${ }^{203} \mathrm{Tl}$ isotopes have allowed us to encircle the ${ }^{204} \mathrm{~Pb}$ in Faraday cups, and thus ${ }^{204} \mathrm{~Pb}$ isotope data acquisition is now well controlled by the addition of a thallium spike in samples (White et al. 2000). This approach has also required the evaluation of a new international standard for Tl (SRM $997 \mathrm{Tl}$ ) (Table 2). Similar to the use of SRM $981 \mathrm{~Pb}$, the SRM $997 \mathrm{Tl}$ values must be considered in making the correction for mass fractionation (White et al. 2000; Thirlwall 2002). Biasing of the isotopic data could be produced either by the choice of a given standard value or by the mathematical law used to correct the mass effect fractionation. In pure geochemistry papers, the SRM $981 \mathrm{~Pb}$ and SRM $997 \mathrm{Tl}$ values used for the analytical session are always tabulated, but in metal provenance studies they are rarely mentioned. This methodological routine is important if we intend to compare different batches of lead 


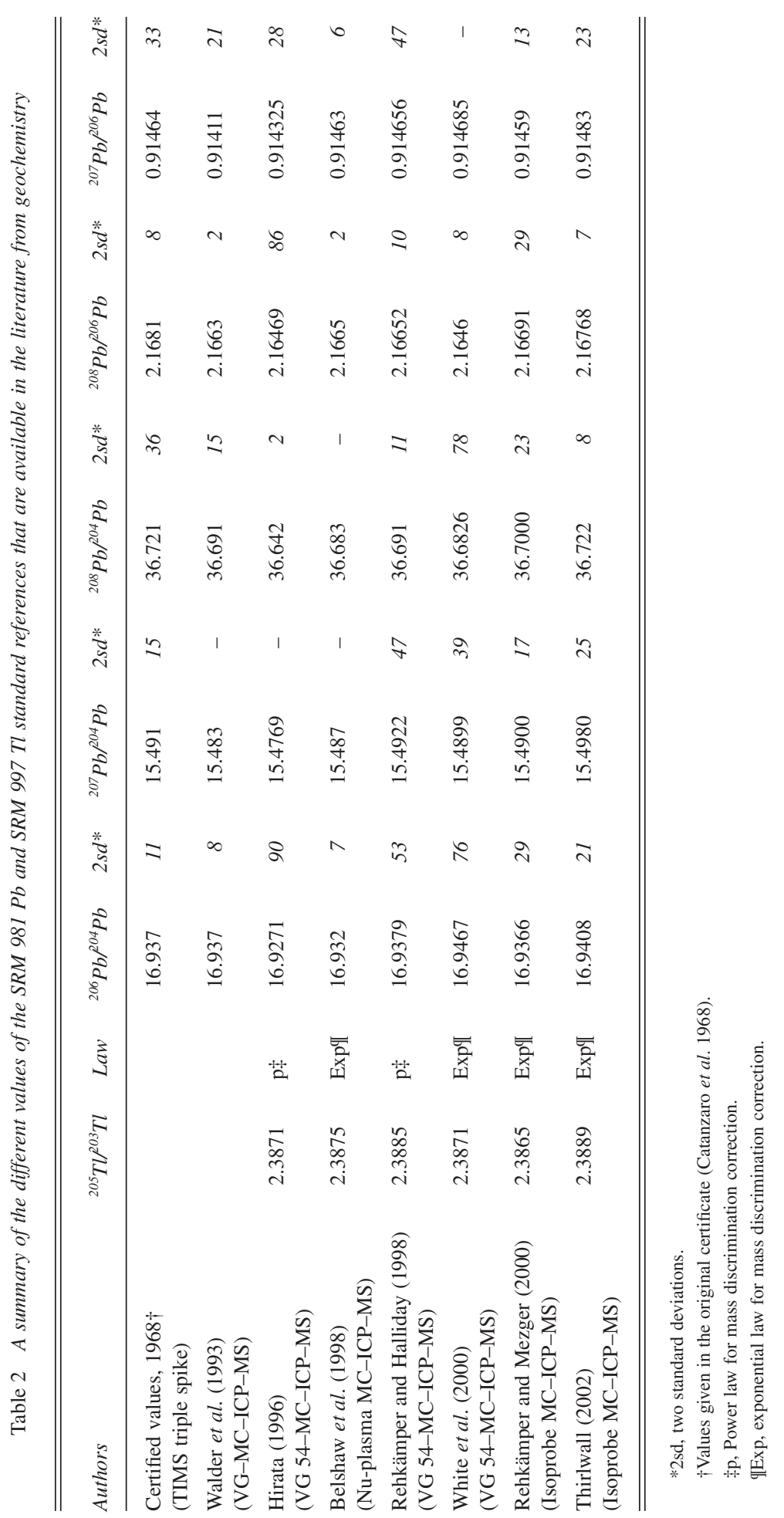


isotopic data (old data from TIMS with new ones from MC-ICP-MS, or batches where MC-ICP-MS was used in both cases).

This problem is confirmed by two batches of isotopic data obtained on the same Roman lead ingots from Saintes-Maries-de-la-Mer (France), which have been acquired by two different laboratories (Fig. 3). TIMS measurements made by Trincherini et al. (2001) and new MC-ICP-MS measurements with Tl doping (Isoprobe equipment located at the CRPG, CNRS laboratory, this study) made on the same ingots are reported in Table 3. Figure 3 shows the lead isotopic data sets between these two isotopic data series for the same archaeological materials. Both series of isotopic analyses are accurate and precise in respect to their SRM $981 \mathrm{~Pb}$ reference values chosen for their analytical sessions. Trincherini et al. (2001) used as reference material the SRM $981 \mathrm{~Pb}$ value proposed in their previous paper (Trincherini et al. 1984), while the original data presented here used the SRM $981 \mathrm{~Pb}$ values of Thirlwall (2002). Thus, the measured isotope ratios between the two data sets are significantly biased. For this reason, it is important to quote these reference values for isotopic comparison in order to correct this artificial bias and thus to improve the metal provenance studies.
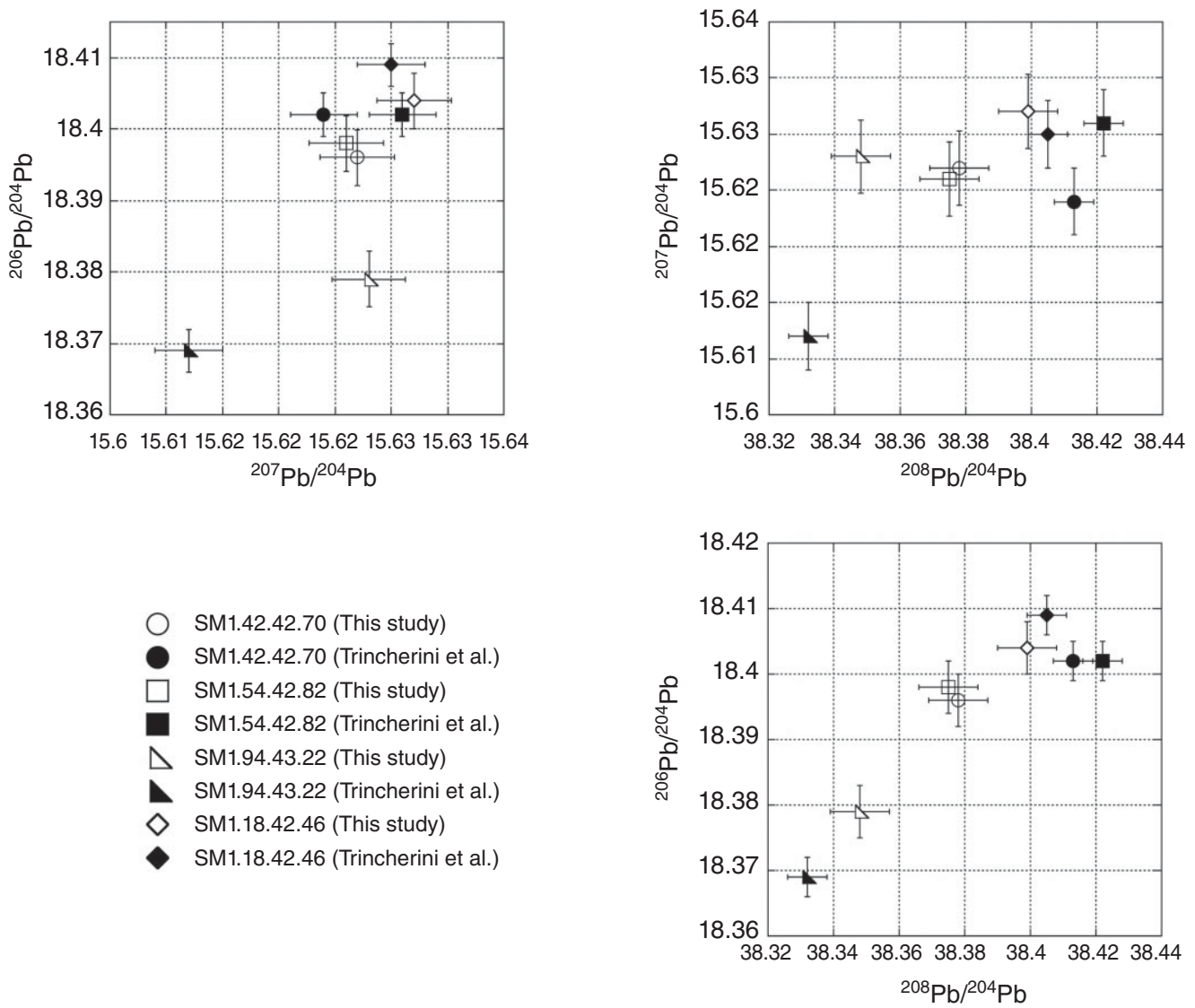

Figure $3 \quad \mathrm{~Pb} / \mathrm{Pb}$ diagrams showing an isotopic bias introduced by different SRM 981 Pb values used during two different analytical sessions. The analyses, in the two cases presented here, are accurate with regard to their own SRM 981 Pb values, but two different SRM 981 Pb values have been chosen to normalize the two sessions. 
Table 3 Lead isotope data of Roman lead ingots from Saintes-Maries-de-la-Mer. The error bars for the Trincherini et al. (2001) ingots measurements are $1 \sigma$ (external errors on the same sample), while for the present study they are $2 \sigma$ (external errors calculated with three triplicates)

\begin{tabular}{|c|c|c|c|c|c|c|}
\hline Ingots Reference & ${ }^{208} \mathrm{~Pb}{ }^{206} \mathrm{~Pb}$ & ${ }^{206} \mathrm{~Pb}{ }^{207} \mathrm{~Pb}$ & ${ }^{207} \mathrm{~Pb} /{ }^{206} \mathrm{~Pb}$ & ${ }^{208} \mathrm{~Pb} /{ }^{204} \mathrm{~Pb}$ & ${ }^{207} \mathrm{~Pb} /{ }^{204} \mathrm{~Pb}$ & ${ }^{206} \mathrm{~Pb} /{ }^{204} \mathrm{~Pb}$ \\
\hline \multicolumn{7}{|l|}{$S M 1.42 .42 .70$} \\
\hline This study (CRPG 2004)* & 2.0862 & 1.1773 & 0.8494 & 38.378 & 15.627 & 18.396 \\
\hline Trincherini et al. $(2001) \dagger$ & 2.0874 & 1.1778 & 0.8490 & 38.413 & 15.624 & 18.402 \\
\hline \multicolumn{7}{|l|}{$S M 1.54 .42 .82$} \\
\hline This study (CRPG 2004)* & 2.0859 & 1.1774 & 0.8493 & 38.375 & 15.626 & 18.398 \\
\hline Trincherini et al. (2001) $\dagger$ & 2.0879 & 1.1773 & 0.8494 & 38.422 & 15.631 & 18.402 \\
\hline \multicolumn{7}{|l|}{ SM1.94.43.22 } \\
\hline This study (CRPG 2004)* & 2.0865 & 1.1761 & 0.8503 & 38.348 & 15.628 & 18.379 \\
\hline Trincherini et al. (2001) $\dagger$ & 2.0868 & 1.1766 & 0.8499 & 38.332 & 15.612 & 18.369 \\
\hline \multicolumn{7}{|l|}{$S M 1.18 .42 .46$} \\
\hline This study (CRPG 2004)** & 2.0865 & 1.1773 & 0.8494 & 38.399 & 15.632 & 18.404 \\
\hline Trincherini et al. $(2001) \dagger$ & 2.0862 & 1.1778 & 0.8490 & 38.405 & 15.630 & 18.409 \\
\hline
\end{tabular}

*The SRM $981 \mathrm{~Pb}$ values used during the analytical session are reported in Thirlwall (2002).

$\dagger$ The SRM $981 \mathrm{~Pb}$ values used during the analytical session are reported in Trincherini et al. $(1984,2001)$.

To address this problem, it would be valuable to indicate whether the precision refers to numerous measurements of NIST SRM $981 \mathrm{~Pb}$ reference material in the same analytical session or if it is based on numerous measurements of three aliquots of the same sample (triplicates with $2 \sigma$ errors). The use of triplicates with $2 \sigma$ errors is better for illustrating the error of samples; it gives a more representative precision on a sample scale. Furthermore, the NIST SRM $981 \mathrm{~Pb}$ standard reference values obtained during analytical sessions should always be reported.

\section{The use of the ${ }^{204} \mathrm{~Pb}$ isotope}

The lead isotope treatments in metal provenance studies are repeatedly assumed to be based on ${ }^{208} \mathrm{~Pb},{ }^{207} \mathrm{~Pb}$, and ${ }^{206} \mathrm{~Pb}$, while the ${ }^{204} \mathrm{~Pb}$ isotope is generally not used. In geochemistry, the use of the ${ }^{207} \mathrm{~Pb} /{ }^{204} \mathrm{~Pb},{ }^{206} \mathrm{~Pb} /{ }^{204} \mathrm{~Pb}$ and ${ }^{208} \mathrm{~Pb} /{ }^{204} \mathrm{~Pb}$ ratios is traditional (e.g., Vitrac et al. 1981 ; Brévart et al. 1982; Marcoux and Bril 1986), but these ratios are ignored in almost all metal provenance studies.

The ${ }^{232} \mathrm{Th},{ }^{238} \mathrm{U}$ and ${ }^{235} \mathrm{U}$ parent isotopes decay at different rates and consequently the resultant $\mathrm{Pb}$ isotope ratios are time dependent, unlike ${ }^{204} \mathrm{~Pb}$, the amount of which has not changed since the Earth's formation. Nevertheless, ${ }^{204} \mathrm{~Pb}$ is the less abundant isotope $(1.24 \%)$, which before the development of MC-ICP-MS was well measured only by a TIMS double or triple spike. As stated earlier, MC-ICP-MS equipment allows a precise and accurate measurement of ${ }^{204} \mathrm{~Pb}$. In many metal provenance studies that now use the MC-ICP-MS instrumentation, the ${ }^{204} \mathrm{~Pb}$ isotope is listed within data tables, but surprisingly ${ }^{207} \mathrm{~Pb} /{ }^{206} \mathrm{~Pb}$ and ${ }^{208} \mathrm{~Pb} /{ }^{206} \mathrm{~Pb}$ ratio plots dominate the representation of isotopic data, even in the most recent literature using MC-ICP-MS (e.g., Niederschlag et al. 2003; Durali-Mueller et al. 2007; Klein et al. 2007, 2009; Bode et al. 2009). The habit of using only ${ }^{207} \mathrm{~Pb} /{ }^{206} \mathrm{~Pb}$ and ${ }^{208} \mathrm{~Pb} /{ }^{206} \mathrm{~Pb}$ ratios dominates the discussions of metal provenance. Archaeologists have not exploited the lead isotope 
patterning through time and space that geologists have accumulated (Albarède et al. 2012). Indeed, a plot of ${ }^{207} \mathrm{~Pb} /{ }^{206} \mathrm{~Pb}$ and ${ }^{208} \mathrm{~Pb} /{ }^{206} \mathrm{~Pb}$ ratios reduces the scope for discussion because the data are aligned along a straight line, thus avoiding any discrimination on the basis of the ore sources, which are controlled by the $\mathrm{U} / \mathrm{Pb}$ and $\mathrm{Th} / \mathrm{Pb}$ ratios of the ore fluids derived from different reservoirs (mantle, crust and so on), contamination during the rise of the fluids, and the age of the ore deposition. Indeed, where there are several ore deposition sequences of slightly different ages, the importance of considering the ${ }^{206} \mathrm{~Pb} /{ }^{204} \mathrm{~Pb},{ }^{207} \mathrm{~Pb} /{ }^{204} \mathrm{~Pb}$ and ${ }^{208} \mathrm{~Pb} /{ }^{204} \mathrm{~Pb}$ ratios is closely tied to the recognition of ore sources. The ${ }^{207} \mathrm{~Pb} /{ }^{206} \mathrm{~Pb}$ and ${ }^{208} \mathrm{~Pb} /{ }^{206} \mathrm{~Pb}$ ratio plots do not discriminate between deposit ages. Thus, the best way of discriminating is to use the ${ }^{207} \mathrm{~Pb} /{ }^{204} \mathrm{~Pb},{ }^{206} \mathrm{~Pb} /{ }^{204} \mathrm{~Pb}$ and ${ }^{208} \mathrm{~Pb} /{ }^{204} \mathrm{~Pb}$ diagrams in the context of model growth curves, and of the time scales that accompany those curves (Cattin et al. 2009; Guénette-Beck et al. 2009). We assume that the normalization of ${ }^{208} \mathrm{~Pb},{ }^{207} \mathrm{~Pb}$ and ${ }^{206} \mathrm{~Pb}$ isotopes to the ${ }^{204} \mathrm{~Pb}$ isotope is an extremely useful representation that allows a significant improvement in metal tracing (Baron et al. 2006, 2011; Villa 2009; Desaulty et al. 2011).

Thus, the main reason for considering the abundance of ${ }^{204} \mathrm{~Pb}$ is that archaeological materials can only be derived from those ores with which they share the same isotopic space, as defined by all the $\mathrm{Pb}$ isotopes. That is consistent with a $3 \mathrm{D}$ space with axes ${ }^{207} \mathrm{~Pb} /{ }^{206} \mathrm{~Pb},{ }^{208} \mathrm{~Pb} /{ }^{206} \mathrm{~Pb}$ and ${ }^{204} \mathrm{~Pb} /{ }^{206} \mathrm{~Pb}$, where the data for archaeological materials must lie within the ore deposit space if the material is to be considered as a potential derivative of the ore.

\section{CONCLUSIONS}

Several ways of improving the significance of $\mathrm{Pb}$ isotopes data in metal provenance studies have been identified and discussed. The present overview starts with observations concerning the field approach; that is, geological and mining archaeological research, and continues with a protocol including the indication of the SRM $981 \mathrm{~Pb}$ values used to derive corrected sample ratios, and processing the acquired data with the use of diagrams in which all three radiogenic $\mathrm{Pb}$ isotopes are ratioed to ${ }^{204} \mathrm{~Pb}$.

Geological and mineralogical studies of the ore deposit/ore district believed to be the source of the metals represent the first step. These studies define the character of the ore(s) from a mineralogical point of view and may define significant trace elements. Only the mining archaeology is further able to confirm an ancient exploitation activity within a mining site. Mining archaeology coupled with geological research represents the only certain way to recognize the ore(s) that were really mined by the ancient miners, and thus to lead to a refinement of the isotopic tracing of the metal(s) through the use of archaeological ores. If the ores exploited by the ancient miners are not available, the dated slags are the best candidates for refining of the isotopic tracing. Metal prills included in metallurgical wastes give relevant information about the average composition of the ore processed on site, as well as about the average composition of the metals (major, minor and trace elements, $\mathrm{Pb}$ isotopes) that occurred within that site at a given time.

MC-ICP-MS analyses, properly normalized using standards, permit the accurate measurement of ${ }^{204} \mathrm{~Pb}$. Normalization of ${ }^{208} \mathrm{~Pb},{ }^{207} \mathrm{~Pb}$ and ${ }^{206} \mathrm{~Pb}$ isotopes to ${ }^{204} \mathrm{~Pb}$ isotope represents a powerful tool, and the use of diagrams involving the ratios of the three radioactive isotopes to ${ }^{204} \mathrm{~Pb}$ can facilitate better discrimination in metal provenance studies.

\section{ACKNOWLEDGEMENTS}

Thanks are due to the two anonymous reviewers for their constructive comments. We offer special thanks to Jean-Marie Pailler for the English-language improvements. The lead 
isotopic measurements were conducted at the CRPG (Centre de Recherches Pétrographiques et Géochimiques), CNRS laboratory (France).

\section{REFERENCES}

Albarède, F., Desaulty, A.-M., and Blichert-Toft, J., 2012, A geological perspective on the use of Pb isotopes in archaeometry, Archaeometry, 54, 853-67.

Allègre, C. J., 2008, Isotope geology, Cambridge University Press, Cambridge, UK.

Baron, S., Laurent, S., Carignan, J., and Ploquin, A., 2006, Medieval lead making on Mont-Lozère Massif (Cévennes, France): tracing ore sources using $\mathrm{Pb}$ isotopes, Applied Geochemistry, 21, 241-52.

Baron, S., Le Carlier, C., Carignan, J., and Ploquin, A., 2009, Archaeological reconstruction of medieval lead production: implications for ancient metal provenance studies and paleopollution tracing by $\mathrm{Pb}$ isotopes, Applied Geochemistry, 24, 2093-101.

Baron, S., Tămaş, C. G., Cauuet, B., and Munoz, M., 2011, Lead isotope analyses of gold-silver ores from Rosia Montana (Romania): a first step of a metal provenance study of Roman mining activity in Alburnus Maior (Roman Dacia), Journal of Archaeological Science, 38, 1090-100.

Belshaw, N. S., Freedman, P. A., O’Nions, R. K., Frank, M., and Guo, Y., 1998, A new variable dispersion doublefocusing plasma mass spectrometer with performance illustrated for $\mathrm{Pb}$ isotopes, International Journal of Mass Spectrometry, 181, 51-8.

Bode, M., Hauptmann, A., and Mezger, K., 2009, Tracing Roman lead sources using lead isotope analyses in conjunction with archaeological and epigraphic evidence-a case study from Augustan/Tiberian Germania, Archaeological and Anthropological Sciences, 1, 177-94.

Brévart, O., Dupré, B., and Allègre, C. J., 1982, Metallogenic provinces and the remobilisation process studied by lead isotopes: lead-zinc ore deposits from the southern Massif Central, France, Economic Geology, 77, 564-75.

Budd, P., Gale, D., Pollard, A. M., Thomas, R. G., and Williams, P. A., 1993, Evaluating lead isotope data: further observations, Archaeometry, 35, 241-7.

Budd, P., Haggerty, R., Pollard, A. M., Scaife, B., and Thomas, R. G., 1996, Rethinking the quest for provenance, Antiquity, 70, 168-74.

Catanzaro, E. J., Murphy, T. J., Shields, W. R., and Garner, E. L., 1968, Absolute isotopic abundance ratios of common, equal-atom, and radiogenic lead isotopic standards, Journal of Research of the National Bureau of Standards-A. Physics and Chemistry, 72A(3), 261-7.

Cattin, F., Igor, V., and Besse, M., 2009, Copper supply during the Final Neolithic at the Saint-Blaise/Bains des Dames site (Neuchâtel, Switzerland), Archaeological and Anthropological Science, 1, 161-76.

Cauuet, B., 2004, L'Or des Celtes du Limousin, Ed. Culture et Patrimoine en Limousin, Limoges.

Cauuet, B., 2005, Mines d'or et d'argent antiques de Dacie. Le district d'Alburnus Maior (Rosia Montana, Roumanie), Nouvelles de l'Archéologie, Paris, no. 100, 38-43.

Cauuet, B., 2008, Equipements en bois dans les mines d'or protohistoriques et antiques (Gaule et Dacie romaine), in Archéologie et paysages des mines anciennes. De la fouille au musée (eds. M.-C. Bailly-Maître, C. JourdainAnnequin and M. Clermont-Joly), 57-73, Ed. A. et J. Picard, Paris.

Cook, N. J., and Chiaradia, M., 1997, Sources of base metal mineralization in the Baia Borsa orefield, NW Romania: constraints from lead isotopes, in Mineral deposits (ed. H. Papunen), 813-16, Balkema, Rotterdam.

Deloule, E., and Allègre, C. J., 1986, Lead and sulphur isotope microstratigraphy in galena crystals from Mississippi valley-type deposits, Economic Geology, 81, 1307-21.

Desaulty, A. M., Telouk, P., Albalat, E., and Albarède, F., 2011, Isotopic Ag-Cu-Pb record of silver circulation through 16th-18th century Spain, Proceedings of the National Academy of Sciences, 108(22), 9002-7.

Domergue, C., 1990, Les mines de la péninsule Ibérique dans l'antiquité romaine, Collection Ecole Française de Rome, vol. 127 , Rome.

Domergue, C., 2008, Les mines antiques, Ed. A. et J. Picard, Paris.

Durali-Mueller, S., Brey, G. P., Wigg-Wolf, D., and Lahaye, Y., 2007, Roman lead mining in Germany: its origin and development through time deduced from lead isotope provenance studies, Journal of Archaeological Science, 34, $1555-67$.

Faure, G., and Mensing, T. M., 2005, Isotopes: principles and applications, 3rd edn, Wiley, Chichester.

Gale, N. H., 1999, Lead isotope characterization of the ore deposits of Cyprus and Sardinia and its application to the discovery of the sources of copper for Late Bronze Age oxhide ingots, in Metals in antiquity (eds. S. M. M. Young, A. M. Pollard, P. Budd and R. A. Ixer), 110-21, British Archaeological Reports, 792, Archaeopress, Oxford. 
Galer, S. J. G., and Abouchami, W., 1998, Practical application of lead triple spiking for correction of instrumental mass discrimination, Mineralogical Magazine, 62A, 491-2.

Goldenberg, G., 1998, L'exploitation du cuivre dans les Alpes autrichiennes à l'âge du Bronze, in L'atelier du bronzier en Europe du XX $X^{e}$ au VIII siècle avant notre ère. Tome II. Du minerai au metal, du metal à l'objet, Cths-Ed. Comité des Travaux, Collection Documents Préhistoriques, Paris.

Guénette-Beck, B., Meissier, N., and Curdy, P., 2009, New insights into the ancient silver production of the Wallis area, Switzerland, Archaeological and Anthropological Sciences, 1, 215-29.

Hauptmann, A., Rehren, Th., and Pernicka, E., 1995, The composition of gold from the ancient mining district of Verespatak/Rosia Montana, Romania, in Prehistoric gold in Europe (eds. G. Morteani and J. P. Northover), 369-81, Kluwer Academic, Dordrecht.

Hirata, T., 1996, Lead isotopic analysis of NIST Standard Reference Materials using multiple collector inductively coupled plasma mass spectrometry coupled with a modified external correction method for mass discrimination, The Analyst, 121, 1407-11.

Ixer, R. A., 1999, The role of ore geology and ores in the archaeological provenancing of metals, in Metals in antiquity (eds. S. M. M. Young, A. M. Pollard, P. Budd and R. A. Ixer), 43-52, British Archaeological Reports, 792, Archaeopress, Oxford.

Klein, S., Domergue, C., Lahaye, Y., Brey, G. P., and von Kaenel, H.-M., 2009, The lead and copper isotopic composition of copper ores from the Sierra Morena (Spain), Journal of Iberian Geology, 35(1), 59-68.

Klein, S., Rico, C., Lahaye, Y., von Kaenel, H.-M., Domergue, C., and Brey, G. P., 2007, Copper ingots from the western Mediterranean Sea: chemical characterisation and provenance studies through lead and copper isotope analyses, Journal of Roman Archaeology, 20(1), 203-21.

Le Guen, M., and Lancelot, J. R., 1989, Origin of the $\mathrm{Pb}-\mathrm{Zn}$ in the mineralization of the southern Cevennes Bathonian, Chronique de la Recherche Minière, 495, 31-6.

Marcoux, E., 1986, Isotopes du plomb et paragénèses métalliques, traceurs de l'histoire des gîtes minéraux. Illustration des concepts de sources, d'héritage et de régionalisme dans les gîtes français, application en recherche minière, Ph.D. thesis, Université de Clermont-Ferrand, France, Document du BRGM, 117.

Marcoux, E., and Bril, H., 1986, Héritage et sources des métaux d'après la géochimie isotopique du plomb. Exemple des minéralisations filonniennes ( $\mathrm{Sb}, \mathrm{Pb}, \mathrm{Ba}, \mathrm{F})$ du Haut-Allier (Massif Central, France), Mineralium Deposita, 21, 35-43.

Mason, T. F. D., Weiss, D. J., Chapman, J. B., Wilkinson, J. J., Tessalina, S. G., Spiro, B., and Horstwood, M. S. A., 2005, $\mathrm{Zn}$ and $\mathrm{Cu}$ isotopic variability in the Alexandrinka volcanic-hosted massive sulphide (VHMS) ore deposit, Urals, Russia, Chemical Geology, 221, 170-87.

Niederschlag, E., Pernicka, E., Seifert, T., and Barelheim, M., 2003, The determination of lead isotope ratios by multiple collector ICP-MS: a case study of Early Bronze Age artefacts and their possible relation with ore deposits of the Erzgebirge, Archaeometry, 45, 61-100.

Pernicka, E., Begemann, F., Schmitt-Strecker, S., and Grimanis, A. P., 1990, On the composition and provenance of metal artifacts from Poliochni on Lemnos, Oxford Journal of Archaeology, 9(3), 263-98.

Ploquin, A., Allée, Ph., Bailly-Maître, M. C., Baron, S., de Beaulieu, J. L., Carignan, J., Laurent, S., Lavoie, M., Mahé-Le Carlier, C., Peytavin, J., and Pulido, M., 2003, Medieval smelting on the Mont-Lozère, southern France, in International conference: Archaeometallurgy in Europe, vol. I, 635-44, Milan.

Poitrasson, F., Halliday, A. N., Lee, D. C., Levasseur, S., and Teutsch, N., 2004, Iron isotope differences between Earth, Moon, Mars and Vesta as possible records of contrasted accretion mechanisms, Earth and Planetary Science Letters, 223, 253-66.

Pollard, A. M., 2008, Lead isotope geochemistry and the trade in metals, in Archaeological chemistry, 2nd edn (eds. A. M. Pollard and C. Heron), 203-345, The Royal Society of Chemistry, London.

Rehkämper, M., and Halliday, A. N., 1998, Accuracy and long-term reproducibility of lead measurements by multiplecollector inductively mass spectrometry using an external method for correction of mass discrimination, International Journal of Mass Spectrometry, 181, 123-33.

Rehkämper, M., and Mezger, K., 2000, Investigation of matrix effects for Pb isotope ratio measurements by multiple collector ICP-MS: verification and application of optimised analytical protocols, Journal of Analytical Atomic Spectrometry, 15, 1451-60.

Rohl, B. M., 1996, Lead isotope data from the Isotrace Laboratory, Oxford: Archaeometry data base 2, galena from Britain and Ireland, Archaeometry, 38, 165-80.

Sayre, E. V., Yener, K. A., Joel, E. C., and Barnes, I. L., 1992, Statistical evaluation of the presently accumulated lead isotope data from Anatolia and surrounding regions, Archaeometry, 34, 73-105. 
Sayre, E. V., Joel, E. C., Blackman, M. J., Yener, K. A., and Özbal, H., 2001, Stable lead isotope studies of the Black Sea Anatolian ore sources and related Bronze Age and Phrygian artefacts from nearby archaeological sites. Appendix: new central Taurus ore data, Archaeometry, 43, 77-115.

Scaife, B., Budd, P., McDonnell, J. G., Pollard, A. M., and Thomas, R. G., 1994, A reappraisal of statistical techniques used in lead isotope analysis, in Archaeometry 94: the proceedings of the 29th International Symposium on Archaeometry (eds. Sุ. Demirci, A. M. Özer and G. D. Summers.), 301-7, Tubitak, Ankara.

Stos-Gale, Z. A., and Gale, N. H., 2009, Metal provenancing using isotopes and the Oxford archaeological lead isotope database (OXALID), Archaeological and Anthropological Science, 1, 195-213.

Stos-Gale, Z. A., Gale, N. H., Houghton, J., and Speakman, R., 1995, Lead isotope data from the isotrace laboratory, Oxford: Archaeometry data base 1, Ores from the Western Mediterranean, Archaeometry, 37, 407-15.

Stos-Gale, Z. A., Maliotis, G., Gale, N. H., and Annetts, N., 1997, Lead isotope characteristics of the Cyprus copper oxhide ingots, Archaeometry, 39, 83-124.

Stos-Gale, Z. A., Gale, N. H., Annetts, N., Todorov, T., Lilov, P., Raduncheva, A., and Panayotov, I., 1998, Lead isotope data from the Isotrace Laboratory, Oxford: Archaeometry data base 5, ores from Bulgaria, Archaeometry, 40, $217-26$.

Tămaş, C. G., Baron, S., and Cauuet, B., 2009, Minéralogie et signature isotopique du plomb des minerais auroargentifères exploités durant l'époque romaine à Alburnus Maior (Roşia Montană, Roumanie), ArcheoSciencesRevue d'Archéométrie, 33, 83-90.

Thirlwall, M. F., 2002, Multicollector ICP-MS analysis of Pb isotopes using a ${ }^{207} \mathrm{~Pb} /{ }^{204} \mathrm{~Pb}$ double spike demonstrates up to $400 \mathrm{ppm} / \mathrm{amu}$ systematic errors in Tl-normalisation, Chemical Geology, 184, 255-79.

Todt, W., Cliff, R. A., Hanser, A., and Hofmann, A. W., 1996, Evaluation of a ${ }^{202} \mathrm{~Pb}-{ }^{205} \mathrm{~Pb}$ double spike for high-precision lead isotope analysis, in Earth processes: reading the isotopic code (eds. A. Basu and S. R. Hart), 429-37, Geophysical Monograph 95, American Geophysical Union, Washington, DC.

Trincherini, P. R., Contini, S., and Perucchini, L., 1984, Determination by mass spectrometry of the isotopic ratio ${ }^{206} \mathrm{~Pb}{ }^{207} \mathrm{~Pb}$ in metal (SRM) and in blood samples, Finnigan MAT Application Note, 49, 5-10.

Trincherini, P. R., Barbero, P., Quarati, P., Domergue, C., and Long, L., 2001, Where do the lead ingots of the Saintes-Maries-de-la-Mer wreck come from? Archaeology compared with physics, Archaeometry, 43, $393-406$.

Villa, I., 2009, Lead isotopic measurements in archaeological objects, Archaeological and Anthropological Sciences, 1, 149-53.

Vitrac, A. M., Albarède, F., and Allègre, C. J., 1981, Lead isotopic composition of Hercynian granitic K-feldspars contrains continental genesis, Nature, 291, 460-4.

Walder, A. J., Platzner, I., and Freedman, P. A., 1993, Isotope ratio measurements of lead, neodymium and neodymiumsamarium mixtures, hafnium and hafnium-lutecium mixtures with a double focused multiple collector inductively coupled plasma mass spectrometry, Journal of Analytical Atomic Spectrometry, 8, 19-23.

White, W. M. F., Albarède, F., and Télouk, P., 2000, High-precision analysis of Pb isotope ratios by multiple-collector ICP-MS, Chemical Geology, 167, 257-70.

Yener, K. A., Sayre, E. V., Joel, E. C., Özbal, H., Barnes, I. L., and Brill, R. H., 1991, Stable lead isotope studies of Central Taurus ore sources and related artifacts from eastern Mediterranean chalcolithic and bronze age sites, Journal of Archaeological Science, 18, 541-77.

Yi, Budd, P., McGill, R. A. R., Young, S. M. M., Halliday, A. N., Haggerty, R., Scaife, B., and Pollard, A. M., 1999, Tin isotope studies of experimental and prehistoric bronzes, in The beginnings of metallurgy (eds. A. Hauptmann, E. Pernicka, T. Rehren and U. Yalcin), 285-90, Der Anschnitt, Beiheft 9. 